\title{
$\beta 1$ Integrins as Therapeutic Targets to Disrupt Hallmarks of Cancer
}

\author{
Anne-Florence Blandin, Guillaume Renner, Maxime Lehmann, Isabelle Lelong-Rebel, \\ Sophie Martin and Monique Dontenwill *
}

Department "Tumoral Signaling and Therapeutic Targets," Faculty of Pharmacy, UMR7213 Centre National de la Recherche

Scientifique, University of Strasbourg, Illkirch, France

\section{OPEN ACCESS}

Edited by:

Hervé Emonard,

Université de Reims

Champagne-Ardenne, France

Reviewed by:

Stéphane Dedieu,

Université de Reims

Champagne-Ardenne, France

Anthony Lemarie,

Institut National de la Santé et de la

Recherche Médicale, France

*Correspondence:

Monique Dontenwill

monique.dontenwill@unistra.fr

Specialty section:

This article was submitted to Pharmacology of Anti-Cancer Drugs,

a section of the journal

Frontiers in Pharmacology

Received: 13 October 2015 Accepted: 05 November 2015 Published: 24 November 2015

Citation:

Blandin A-F, Renner G, Lehmann M, Lelong-Rebel I, Martin $S$ and

Dontenwill M (2015) $\beta 1$ Integrins as

Therapeutic Targets to Disrupt Hallmarks of Cancer.

Front. Pharmacol. 6:279.

doi: 10.3389/fphar.2015.00279
Integrins belong to a large family of $\alpha \beta$ heterodimeric transmembrane proteins first recognized as adhesion molecules that bind to dedicated elements of the extracellular matrix and also to other surrounding cells. As important sensors of the cell microenvironment, they regulate numerous signaling pathways in response to structural variations of the extracellular matrix. Biochemical and biomechanical cues provided by this matrix and transmitted to cells via integrins are critically modified in tumoral settings. Integrins repertoire are subjected to expression level modifications, in tumor cells, and in surrounding cancer-associated cells, implicated in tumor initiation and progression as well. As critical players in numerous cancer hallmarks, defined by Hanahan and Weinberg (2011), integrins represent pertinent therapeutic targets. We will briefly summarize here our current knowledge about integrin implications in those different hallmarks focusing primarily on $\beta 1$ integrins.

Keywords: integrins, hallmarks of cancer, proliferation, migrationinvasion, resistance to cell death, angiogenesis, therapeutic target

\section{INTRODUCTION}

In the setting of cancer, six hallmarks enabling a cell to become tumorigenic and ultimately malignant have been defined by Hanahan and Weinberg (2000). As such cancer cells have the abilities to sustain proliferative signaling, to evade growth suppressors, to resist to cell death, to enable replicative immortality, to induce angiogenesis and to activate invasion and metastasis. This list has been extended recently by the authors taking into account the new progresses made in the past decade with the proposal of two new hallmarks comprising the reprogramming of energy metabolism and the evasion of immune destruction (Hanahan and Weinberg, 2011). A recent review emphasized the modulation of these hallmarks by the extracellular matrix (Pickup et al., 2014). Integrins belong to one of the most studied family of matricellular receptors. These heterodimeric $\alpha \beta$ cell surface receptors sense the extracellular matrix with high flexibility (Hanein and Horwitz, 2012; Hohenester, 2014) triggering thereby specific answers in both physiological and pathophysiological conditions. In humans, $18 \alpha$ and $8 \beta$ subunits have been characterized enabling about 24 heterodimeric combinations. The Arg-Gly-Asp (RGD) binding integrins belong to the most studied subfamily including $\alpha \mathrm{v} \beta 1, \alpha \mathrm{v} \beta 3, \alpha \mathrm{v} \beta 5, \alpha \mathrm{v} \beta 6, \alpha \mathrm{v} \beta 8, \alpha 5 \beta 1$, and $\alpha \operatorname{IIb} \beta 3$. The RGD motif is available in ECM components such as fibronectin, vitronectin, osteopontin, and fibrinogen. Cell binding to collagen or laminin involves either $\beta 1(\alpha 1 \beta 1, \alpha 2 \beta 1, \alpha 10 \beta 1, \alpha 11 \beta 1, \alpha 6 \beta 1 \ldots)$ or $\beta 4(\alpha 6 \beta 4 \ldots)$ subunits-containing integrins. Integrins signaling operates through the integrin adhesome which appears complex (Winograd-Katz et al., 2014). Interactions of integrins with soluble or membrane-localized elements as well as with cytoplasmic adaptors or catalytic partners 
(kinases, phosphatases, proteases ...) define series of coordinated and spatiotemporal regulated processes. Mechanistic insights into the fine tuning of integrin signaling thereby revealing the high versatility of the cell answer to integrin-driven stimuli were enabled by the development of new technologies (Rossier et al., 2012; Robertson et al., 2015). Expression and activity of integrins and of their adhesome components have been implicated in various diseases including cancer. Integrins are well recognized as valuable tumor therapeutic targets although essentially in preclinical studies (Desgrosellier and Cheresh, 2010; Schaffner et al., 2013). A recent review emphasized their capability to regulate cancer stemness, metastasis, and drug resistance (Seguin et al., 2015). They remarkably impact on the hallmarks of cancer as defined above. In this review, our aim is to update the knowledges with the most recent data in the field focusing particularly on $\beta 1$ integrins and their roles in the tumor progression. Integrins containing the $\beta 1$ subunit constitute the largest subgroup and appear overexpressed in several solid tumors compared to control tissues (Paulus et al., 1993; Barkan and Chambers, 2011; Fabricius et al., 2011; Lahlou and Muller, 2011; Schaffner et al., 2013).

\section{INTEGRINS AND A SUSTAINED PROLIFERATIVE SIGNALING}

Integrins contribute to the cell cycle progression in physiological and pathological situations (reviewed in Moreno-Layseca and Streuli, 2014). The cross-talk between integrins and growth factor receptors (GFR) is well established especially in sustaining the cell proliferative signaling. Several GFR are concerned of which the epidermal growth factor receptor (EGFR), the hepatocyte growth factor receptor (HGFR/cMet), the platelet-derived growth factor receptor (PDGFR) and the vascular endothelial growth factor receptor (VEGFR). Direct activation of GFR by integrins was first described in normal cells. In endothelial cells, integrins phosphorylate EGFR even in the absence of EGF (Moro et al., 2002). More recently, $\beta 1$ integrin downregulation decreased the phosphorylation of c-Met and of EGFR in hepatocytes during liver regeneration (Speicher et al., 2014). Keratinocytes stimulation by EGF modulates constituents of focal adhesion complexes including $\beta 1 / \beta 3$ integrins and FAK (Eberwein et al., 2015). The synergistic relationship between integrins and GFR is also highlighted in tumor progression (Ivaska and Heino, 2011). Physical interactions between integrins and GFR have been demonstrated by co-immunoprecipitation experiments ( $\alpha 5$ integrin and EGFR; Morozevich et al., 2012) or by FRET analysis on patient tumor slices ( $\beta 1$ integrin and ERBB1; Petras et al., 2013). Interestingly, proliferative cooperation between ECM receptors and GFR may also be achieved through direct ECM-GF interactions (Vlahakis et al., 2005; Oommen et al., 2011; Dong et al., 2014; Han et al., 2014; Zhu and Clark, 2014). The fine molecular tuning of the integrin-GFR interplay implicates other partners either from the ECM or from the cellular compartment. The matricellular protein CCN1 (CYR61/CCN1, cysteine-rich protein 61) inhibits EGFR-dependent hepatocytes proliferation through ROS accumulation induced by $\alpha 6 \beta 1$ integrin in liver carcinoma (Chen et al., 2015). Tenascin- $\mathrm{C}$ induces a physical association of PDGFR- $\beta$ and $\alpha 5 \beta 1$ integrin resulting in prolonged activation of PDGFR- $\beta$ and deregulated proliferation of fibroblast cell line (Tanaka et al., 2014). EGFR signaling regulates ILK (Integrin Linked Kinase) to increase gastric cancer cells proliferation (Tseng et al., 2014). In epidermoid carcinoma cells, EGF stimulation modulates $\alpha 5 \beta 1$ activation state by phosphorylation of Filamin-A (Vial and McKeownLongo, 2012). In the same model, $\alpha 5 \beta 1$ integrin inhibition reduces EGFR phosphorylation implicated in cell proliferation (Morozevich et al., 2012). Scaffolding proteins such as tensin4 (TNS4) may create a functional complex between cMet and integrin $\beta 1$ (Muharram et al., 2014). Hepatocellular carcinoma progression has been blocked by nanoparticle-formulated siRNA targeting $\beta 1$ and $\alpha v$ integrins through reduced activation of MET oncogene (Bogorad et al., 2014). Integrins and GFR thus mainly interact through cross-regulated signaling pathways. In the case of EGFR and $\alpha 5 \beta$ 1integrin, common way of intracellular trafficking may also potentiate their functions (Caswell et al., 2008). The overexpression of GFR and/or the expression of constitutively active mutants (such as the EGFRvIII mutant; Guo et al., 2015) are hallmarks of different tumor types and boost the proliferation of tumoral cells. Powerful therapeutic strategies may thus include simultaneous integrin/GFR targeting for selected tumors and patients (Eke et al., 2015).

\section{INTEGRINS AND THE EVASION OF GROWTH SUPPRESSORS AND THE RESISTANCE TO CELL DEATH}

\section{Evading Growth Suppressor}

p53 one of the most prominent tumor suppressor, is mutated in about $50 \%$ of cancers (Ciriello et al., 2013). Wild type p53 signaling is nevertheless altered in a large majority of tumors by alternative pathways such as deletions/mutations of endogenous activators or amplifications of inhibitors (Brennan et al., 2013). Integrin signaling may be added to the list of p53 activity regulators. We have shown that $\alpha 5 \beta 1$ integrin impairs the p53 activation by chemotherapeutic drugs (Martinkova et al., 2010; Janouskova et al., 2012, 2013; Martin et al., 2012). Similar results obtained by others in breast carcinoma cells showed enhanced expression of $\mathrm{p} 53$ upon depletion of $\alpha 2 \beta 1$ integrin (Morozevich et al., 2015). In glioblastoma, an overexpression of $\alpha 5$ integrin was recorded in p53 wild type tumors (Janouskova et al., 2012) explaining their resistance to therapies. Conversely, in ovarian tumors with a mutated p53 overexpression of the $\beta 4$ integrin leads to a metastasis advantage (Lee et al., 2015). In squamous cell carcinoma, cooperation between p53 and $\alpha \mathrm{v}$ integrin, impacts on tumor induction and growth (Savar et al., 2015). Integrin signaling pathways have been highlighted in the regulation of p53 activity. Our recent data demonstrated participation of the integrin/AKT/PEA15/caspase 8 axis in the inhibition of p53 (Renner et al., 2015). As reported by others, the integrindownstream kinase FAK, has the capability to inhibit p53 through direct physical interaction in the nucleus or cytoplasm thus linking signaling from the ECM to the nucleus (Golubovskaya 
and Cance, 2011; Golubovskaya, 2014). Interestingly, a regulatory loop exists between FAK and p53 (Golubovskaya et al., 2008) similar to the one we described between $\alpha 5$ integrin and p53 (Renner et al., 2015). Finally, abrogation of $\alpha 5$ integrin or FAK signaling concomitantly with activation of p53 leads to tumor cell apoptosis (Gillory et al., 2015; Renner et al., 2015). Reactivation of p53 appears as a pertinent strategy for numerous tumors (Selivanova, 2014) and, as suggested above, blocking either integrins or their downstream signaling pathways may offer new opportunities to synergistically enhance the p53 tumor suppressor effects.

\section{Resisting Cell Death}

Maintenance of cell survival through ECM-integrin interactions has been recognized for a long time in development and in tissue homeostasis. Loss in cell adhesion will block the pro-survival integrin-dependent signaling pathways including PI3K/AKT, MEK/ERK, FAK, NFKB, and/or ILK leading to a particular form of apoptosis named anoikis (Griffiths et al., 2011; Vachon, 2011). Resistance to anoikis promotes tumor progression and favors emergence of metastasis (Paoli et al., 2013; Buchheit et al., 2014). The "integrin switch" includes changes in their expression profile and functionality during cell detachment from the ECM thus overcoming anoikis and allowing tumor cell survival and metastasis (Janes and Watt, 2004). New contributors to anoikis resistance through integrin pathway modulations were recently discovered. In melanoma cells, TIMP1, a member of the metalloproteinase inhibitors, was shown to form a complex with CD63 and integrin $\beta 1$ conferring resistance to anoikis (Toricelli et al., 2013). Depletion of cytoplasmic FER, a non-receptor tyrosine kinase, by increasing the expression of $\alpha 6 \beta 1$ integrin decreased anoikis resistance in breast cancer cells (Ivanova et al., 2013). Vacuolar-ATPase inhibitor has been shown to reduce active $\beta 1$ integrins and to regulate anoikis resistance in several cancer cells (Schempp et al., 2014). Zinc finger transcription factor ZNF304 transcriptionally regulates the $\beta 1$ integrin and prevents anoikis (Aslan et al., 2015). The miR-26a targeting of $\alpha 5$ integrin promotes anoikis in human hepatocellular carcinoma (Zhang et al., 2015b). Finally, atypical anoikis involving necrosis and autophagy in glioma cells was induced by cilengitide, an $\alpha v \beta 3 / \beta 5$ integrin inhibitor (Silginer et al., 2014). Very recently, suppression of anoikis was attributed to integrin endosomal signaling (Alanko et al., 2015). These recent examples document the different ways for a tumoral cell to engage for resisting to cell-detachment induced apoptosis by means of modulation of integrin expression and functions.

\section{Resistance to Therapies as a Consequence}

As the therapeutic protocols aim to eradicate the tumors and avoid recurrences, the best strategy would be to induce cell death. As supported by their pro-survival capacities, integrins participate to the resistance toward therapies including radio-, chemo- and targeted therapies (Aoudjit and Vuori, 2012; Nistico et al., 2014; Shishido et al., 2014; Eke and Cordes, 2015; Naci et al., 2015).

Research from the group of Cordes largely confirmed that $\beta 1$ integrins induce radioresistance in head and neck cancers
(Eke et al., 2012, 2015; Dickreuter et al., 2015; Steglich et al., 2015) whereas similar results have been reported by others in breast cancer (Nam et al., 2009, 2013; Ahmed et al., 2013). Resistance to radiotherapy has also been linked to $\alpha \mathrm{v} \beta 3 / \beta 5$ integrins (Monferran et al., 2008; Skuli et al., 2009; Ning et al., 2010; Ducassou et al., 2013; Lanvin et al., 2013). $\beta 1$ integrins also modulate solid tumor responses to chemotherapies (Howe and Addison, 2012; Sorensen et al., 2015). In glioblastoma, we demonstrated the crucial role of $\alpha 5 \beta 1$ integrin in the resistance to Temozolomide (Martinkova et al., 2010; Janouskova et al., 2012). IGFBP-2 was involved in this resistance (Holmes et al., 2012; Han et al., 2014). Chemoresistance against doxorubicin by means of $\alpha 2 \beta 1$ integrin activation was recently noted in leukemia (Naci et al., 2012). Interestingly, an anchorage-independent form of chemoresistance may exist in leukemia cells implicating only the $\alpha$ integrin subunit and its cytoplasmic tail sequence KXGFFKR (Liu et al., 2013). If confirmed in other tumors, this will constitute a new concept in the field of integrin-dependent chemoresistance.

Integrins are also coopted candidates for innate and acquired resistance provoking tumor recurrence. In melanoma, the mutant BRAF inhibitor, vemurafenib, drives an adhesion signaling network involving $\alpha 5 \beta 1$ integrin and implicated in the drug resistance (Fedorenko et al., 2015). BRAF inhibition also activated a $\beta 1$ integrin/FAK signaling pathway in the fibroblastic tumor stroma promoting tumoral cell survival (Hirata et al., 2015). In breast cancer cells, acquired resistance to tamoxifen is mediated by cancer-associated fibroblast-derived fibronectin which induces $\beta 1$ integrin-dependent signaling in adjacent tumoral cells (Yuan et al., 2015). Ovarian taxol-resistant tumor populations exhibit an increase in $\beta 1$ integrin expression and microtubule dynamics (McGrail et al., 2015). One of the most studied resistance mechanism addresses the integrinGFR crosstalk. The importance of $\alpha v \beta 3$ integrin/KRAS axis in the resistance of various solid tumors toward EGFR targeted therapies has been demonstrated (Seguin et al., 2014). $\beta 1$ integrin is also implicated in resistance to anti-EGFR therapies (Huang et al., 2011; Morello et al., 2011; Eke et al., 2013; Kanda et al., 2013). By contrast, a recent study showed that $\beta 1$ integrin and EGFR inhibitions are inefficient for radio- and chemosensitization of colorectal carcinoma cell in vitro (Poschau et al., 2015). Cooperation between $\beta 1$ integrin and c-Met regulates tyrosine kinase inhibitor resistance in lung cancer (Ju and Zhou, 2013).

In solid tumors, as resistance to therapies can be mediated by GFR and $\beta 1$ integrin, targeting of $\beta 1$ integrin simultaneously with GFR inhibitors may be a promising therapeutic approach. In addition, new data stress side-effects of targeted therapies on the tumor-surrounding microenvironment that may affect the integrin signaling pathways to reinforce their resistance mechanisms.

\section{INTEGRINS AND INVASION/METASTASIS}

Other key biological process of cancer progression comprises local invasion and metastatic dissemination of tumor cells which present interconnected pathways with resistance to therapies 
(Alexander and Friedl, 2012). Cell adhesion to ECM is central to the migration/invasion/metastasis process and implicates largely integrins (Scales and Parsons, 2011; Esposito and Kang, 2014; Naci et al., 2015). It is known for a long time that integrins regulate MMPs (matrix metalloproteinases) facilitating ECM degradation and remodeling. New data extend these findings (Borrirukwanit et al., 2014; Missan et al., 2015; Schlomann et al., 2015). New components are still being discovered contributing to the activity/function of integrins in cancer. Among those, actinbinding proteins or nucleation/assembly factors were recently reported to play crucial roles in the proinvasive activity of integrins. High expression of Profilin-1 (PFN1-a regulator of actin polymerization) was associated to tumor infiltration and lymph node metastasis. In gastric cancer, silencing PFN1 reduced $\beta 1$ integrin expression and prevented FAK signaling (Cheng et al., 2015). Formin-like 2 (FMNL2-actin nucleation and assembly factor), upregulated in several metastatic cancers, interacts with RhoC to drive $\alpha 2 \beta 1$ and $\alpha 5 \beta 1$ integrin internalization/trafficking and invasive motility of cancer cells (Wang et al., 2015). Invasive migration of cancer cells into fibronectin-rich 3D ECM was reported to be enhanced following Rab-coupling protein (RCP)driven endocytic recycling of $\alpha 5 \beta 1$ integrin. Invasive cells exhibit dynamic actin spike protrusions that are Arp2/3-independent but requires ROCK-mediated activation of FHOD3 (member of the formin family of protein; Paul et al., 2015). Integrin signaling can be rewired to increase tumor invasiveness during tumor metastasis by a novel mechanism recently described (Leyme et al., 2015). Integrins and G protein-coupled receptor traditionally trigger independent signaling but interestingly it was shown that integrin signaling requires the activation of the trimeric G protein Gai by GIV or Girdin. In breast cancer cells, GIV colocalize with $\beta 1$ integrin in invadosomes to recruit Gai3 to the integrin signaling complex. Expression of GIV in non-invasive cancer cells results in enhanced haptotaxis and invasion. Modulation of expression of integrins is an alternative mechanisms used by cancer cells to control migration, invasion and metastasis. Human telomerase reverse transcriptase (hTERT) expression and telomerase activation are observed in $90 \%$ of human malignancies. hTERT plays an important role in cancer invasion by enhancing $\beta 1$ integrin to promote the invasion of gastric cancer ( $\mathrm{Hu}$ et al., 2015). The collaboration between integrins and GFR also accelerate tumor cell mobility and invasion. Clinical and functional analyses showed that CD151 and $\alpha 3 \beta 1$ integrin were elevated in glioblastoma. Both synergized with EGF/EGFR to accelerate tumor cell motility and invasion (Zhou et al., 2015). $\beta 1$ integrin/kindlin and EGFR complexes increase breast and lung cancer cell migration ( $\mathrm{Li}$ et al., 2013; Williams and Coppolino, 2014; Guo et al., 2015). Fibronectin matrix mediates PDGFR- $\beta$ association with $\alpha 5 \beta 1$ integrin in focal adhesions and regulates cell migration (VeeversLowe et al., 2011). HGF-mediated c-Met activation induces collective cancer cell invasion through $\beta 1$ integrin trafficking (Mai et al., 2014). All these data suggest that $\beta 1$ integrins and GFR share the same signaling pathways to modulate migration of cancer cells. In human colorectal cancer, downregulation of the aryl hydrocarbon receptor nuclear translocator (ARNT or HIF-1 $\beta$ ) promoted cancer cell migration and invasion through the activation of the fibronectin/ $\beta 1$ integrin/FAK signaling axis. Chemotherapeutic drugs inhibited ARNT expression and promoted invasion of residual tumor cells (Huang et al., 2015). In head and neck squamous cell carcinoma, disappearance of caveolin-1 expression in primary tumors is predictive of high risk of metastasis and is of bad prognosis. $\alpha 2 \beta 1$ and $\alpha 5 \beta 1$ integrins, both of which are regulated by caveolin-1, are responsible for the acquisition of motile, invasive, evasive and metastatic traits of tumors (Jung et al., 2015). MiR targeting of integrins represents a new way to endogenously regulate their expression. By targeting directly kindlin-2, miR-200b silenced the kindling-2/ $\beta 1$ integrin/AKT regulatory axis that ultimately suppresses the invasiveness of esophageal squamous cancer cells. miR-25 acts as a tumor suppressor in prostate cancer by direct functional interaction with the 3'UTR regions of proinvasive $\alpha v$ and $\alpha 6$ integrins (Zhang et al., 2015a; Zoni et al., 2015).

The tumor cell dissemination to a particular metastatic niche is dependent on the integrin repertoire expressed at the surface of cancer cells, blood and lymph compartment, vasculature, stromal cells as well as the composition and organization of ECM. For instance, a hepatic microenvironment favors the expression of $\alpha 2 \beta 1$ and $\alpha 5 \beta 1$ integrins on colorectal cancer cells which prompted colorectal cancer metastases to settle in the liver (Pelillo et al., 2015). $\alpha \mathrm{v} \beta 3, \alpha 2 \beta 1$ and $\alpha 4 \beta 1$ integrins play a key role in bone metastasis as their ligands are normally expressed by the bone-associated cells (Esposito and Kang, 2014). Knock-out mice for $\alpha 11 \beta 1$ integrin, a stromal cell-specific receptor for fibrillar collagen overexpressed by carcinomaassociated fibroblasts (CAF), prevent the metastatic potential of lung adenocarcinoma cells to bone, kidney, or brain (Navab et al., 2015). Lymph node metastasis (LNM) is recognized in clinical medicine as of bad prognosis for HNSCC patient. $\alpha 2 \beta 1, \alpha 3 \beta 1$, $\alpha 6 \beta 1$ integrins were identified as specific receptors that mediate the interactions between tumor cells and laminin present in the lymphatic environment (Fennewald et al., 2012; Soares et al., 2015).

\section{INTEGRINS AND NEOANGIOGENESIS}

The role of integrins in developmental and pathological angiogenesis has been largely described (Avraamides et al., 2008). As a leader, the $\alpha v \beta 3 / \beta 5$ integrin was long considered as a primordial player in tumoral neo-angiogenesis and its specific antagonist cilengitide was the first to reach clinical trials as an anti-angiogenic compound (Stupp et al., 2010). Unfortunately, cilengitide failed to improve the overall survival of glioblastoma patients in a multicentric randomized phase III clinical trial (Stupp et al., 2014). The need to understand the fine molecular events supporting integrin biology and functions appears currently as a priority in the field (Atkinson et al., 2014). Recent data indicate that dosage and timing of $\alpha v \beta 3$ integrin antagonism are critical to pro- or antiangiogenesis effects (Robinson et al., 2009; Steri et al., 2014). Hence, proof of principle that low doses of cilengitide, which were shown to promote angiogenesis, may be used in a "vascular promotion therapy," opens a new field in integrin 
antagonist usefulness (Wong et al., 2015). Integrin $\alpha 5 \beta 1$ was also highlighted as a pro-angiogenic driver with an increased expression in neo-angiogenic tumoral vessels (Schaffner et al., 2013). However, recent data using KO mice models challenged the implication of $\alpha 5, \alpha \mathrm{v}$ and their matrix ligand fibronectin in the tumor angiogenesis (Murphy et al., 2015). Discrepancies observed between the effects of the gene deletions and those of integrin-matrix adhesion blocking compounds on angiogenesis led to the interesting hypothesis that the latter may induce some anti-angiogenic function in the integrins. A better understanding of the integrin signaling pathways will help to understand their fine tuning in endothelial cells. Recent data explored the molecular regulation of angiogenesis through $\beta 1$ integrin activation/inhibition and revealed cross-talks between angiopoietin-2, Arf6, VE-cadherin or MAP4K4 and $\beta 1$ pathway (Hakanpaa et al., 2015; Hongu et al., 2015; Vitorino et al., 2015; Yamamoto et al., 2015).

Integrins also participate to anti-angiogenic therapy resistance. One of the most studied anti-angiogenic therapy is Bevacizumab, a monoclonal antibody against VEGF-A. Addition of Bevacizumab to adjuvant therapies in multiple cancer types improved progression free survival of patients (Ahmadizar et al., 2015). In brain tumors, anti-VEGF therapy led to bevacizumab-resistant recurrent glioblastoma with two different phenotypes, one of which appeared as infiltrative and the other as proliferative (de Groot et al., 2010; DeLay et al., 2012). Interestingly, the former expressed more $\alpha 5 \beta 1$ integrin and fibronectine. $\beta 1$ integrin targeting was shown to disrupt the resistance toward Bevacizumab (Carbonell et al., 2013; Jahangiri et al., 2014).

\section{INTEGRINS AND REPROGRAMMING OF ENERGY METABOLISM AND THE EVASION OF IMMUNE DESTRUCTION}

Unlike normal cells, tumor cells use aerobic glycolysis (the Warburg effect) rather than oxidative phosphorylation (OXPHOS) to generate energy. This reprogramming of glucose metabolism is promoted by Twist through a $\beta 1$ integrin/FAK/PI3K/AKT/mTOR pathway (Yang et al., 2015). Interestingly, it was shown recently that aerobic glycolysis or OXPHOS deregulation may enhance cancer cell migration and invasion through modulation of $\beta 1$ integrin pathway (Yang et al., 2014; Nunes et al., 2015). Concerning the immune system, $\alpha \mathrm{v}$ integrin upregulation can promote ADCC (antibody-dependentcell-mediated cytotoxicity) but also link drug resistance with immune evasion (Jinushi et al., 2012; Anikeeva et al., 2014). Local immune response can be abrogated by tenascin $\mathrm{C} / \alpha 5 \beta 1$ integrin to promote metastasis (Jachetti et al., 2015). A phenomenom named "integrin transregulation" can enhance tumor immunity through an increase in T-cell entry into melanomas (Cantor et al., 2015). Innate immune cells can promote tumor metastasis in dedicated environment. Interestingly, it was proposed that immune cell-derived microparticles may transfer $\alpha \mathrm{M} \beta 2$ integrin to tumor cells leading to their migration in vitro and metastasis

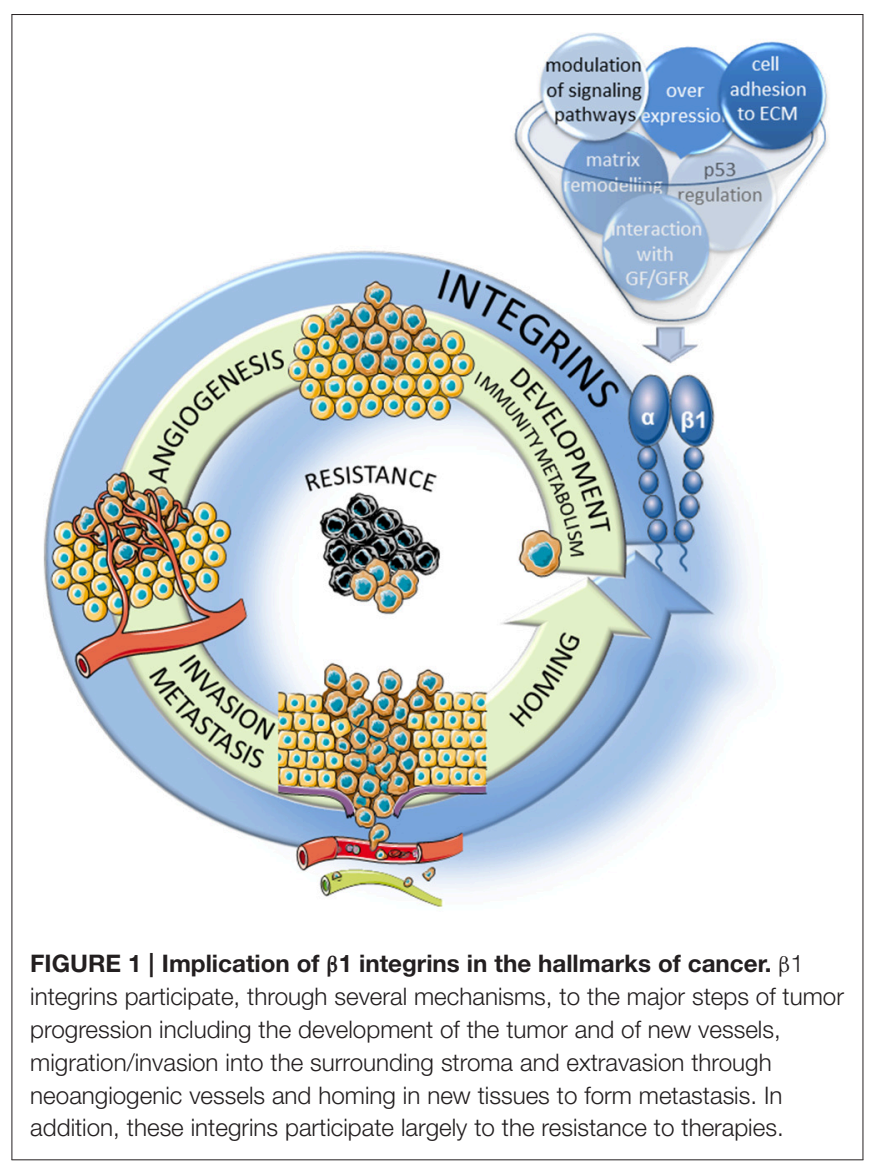

in vivo (Ma et al., 2013). This recent literature suggests that an exponential growth of data will be available in the future characterizing the roles of integrins in these two new hallmarks of cancer.

\section{CONCLUSIONS}

The goal of this review was to give a brief and non-exhaustive overview of the most recent data about the implication of $\beta 1$ integrins in different hallmarks of cancer (Figure 1). Examples given here stress the complexity of the integrin signaling pathways which will largely depend on the tumor context under consideration. Micro environmental cues as well as molecular features of the tumoral cells themselves will determine which integrin(s) may be preferentially targeted. Increasing knowledge on how the integrin expression and functions are modulated is mandatory to propose associated therapies more susceptible to eradicate tumors.

\section{AUTHOR CONTRIBUTIONS}

MD planned and edited the manuscript; AB, GR, SM, IL, and ML made the experiments leading to the laboratory publications cited in the review; $\mathrm{AB}, \mathrm{GR}, \mathrm{ML}, \mathrm{IL}, \mathrm{SM}$, and MD wrote the manuscript. 


\section{ACKNOWLEDGMENTS}

We sincerely apologize to those whose work we were unable to discuss due to space limitations. Work in the authors laboratory is supported by the Ligue Contre le Cancer (Comité du Grand

\section{REFERENCES}

Ahmadizar, F., Onland-Moret, N. C., de Boer, A., Liu, G., and Maitland-van der Zee, A. H. (2015). Efficacy and safety assessment of the addition of bevacizumab to adjuvant therapy agents in cancer patients: a systematic review and metaanalysis of randomized controlled trials. PLOS ONE 10:e0136324. doi: 10.1371/ journal.pone.0136324

Ahmed, K. M., Zhang, H., and Park, C. C. (2013). NF-kappaB regulates radioresistance mediated by betal-integrin in three-dimensional culture of breast cancer cells. Cancer Res. 73, 3737-3748. doi: 10.1158/0008-5472.CAN12-3537

Alanko, J., Mai, A., Jacquemet, G., Schauer, K., Kaukonen, R., Saari, M., et al. (2015). Integrin endosomal signalling suppresses anoikis. Nat. Cell Biol. 17, 1412-1421. doi: $10.1038 /$ ncb3250

Alexander, S., and Friedl, P. (2012). Cancer invasion and resistance: interconnected processes of disease progression and therapy failure. Trends Mol. Med. 18, 13-26. doi: 10.1016/j.molmed.2011.11.003

Anikeeva, N., Steblyanko, M., Fayngerts, S., Kopylova, N., Marshall, D. J., Powers, G. D., et al. (2014). Integrin receptors on tumor cells facilitate NK cellmediated antibody-dependent cytotoxicity. Eur. J. Immunol. 44, 2331-2339. doi: 10.1002/eji.201344179

Aoudjit, F., and Vuori, K. (2012). Integrin signaling in cancer cell survival and chemoresistance. Chemother. Res. Pract. 2012:283181. doi: $10.1155 / 2012 / 283181$

Aslan, B., Monroig, P., Hsu, M. C., Pena, G. A., Rodriguez-Aguayo, C., GonzalezVillasana, V., et al. (2015). The ZNF304-integrin axis protects against anoikis in cancer. Nat. Commun.6, 7351. doi: 10.1038/ncomms8351

Atkinson, S. J., Ellison, T. S., Steri, V., Gould, E., and Robinson, S. D. (2014). Redefining the role(s) of endothelial alphavbeta3-integrin in angiogenesis. Biochem. Soc. Trans. 42, 1590-1595. doi: 10.1042/BST2010206

Avraamides, C. J., Garmy-Susini, B., and Varner, J. A. (2008). Integrins in angiogenesis and lymphangiogenesis. Nat. Rev. Cancer 8, 604-617. doi: $10.1038 / \mathrm{nrc} 2353$

Barkan, D., and Chambers, A. F. (2011). betal-integrin: a potential therapeutic target in the battle against cancer recurrence. Clin. Cancer Res. 17, 7219-7223. doi: 10.1158/1078-0432.CCR-11-0642

Bogorad, R. L., Yin, H., Zeigerer, A., Nonaka, H., Ruda, V. M., Zerial, M., et al. (2014). Nanoparticle-formulated siRNA targeting integrins inhibits hepatocellular carcinoma progression in mice. Nat. Commun. 5, 3869. doi: $10.1038 /$ ncomms4869

Borrirukwanit, K., Pavasant, P., Blick, T., Lafleur, M. A., and Thompson, E. W. (2014). High threshold of betal integrin inhibition required to block collagen I-induced membrane type-1 matrix metalloproteinase (MT1-MMP) activation of matrix metalloproteinase 2 (MMP-2). Cancer Cell Int. 14:99. doi: 10.1186/s12935-014-0099-3

Brennan, C. W., Verhaak, R. G., McKenna, A., Campos, B., Noushmehr, H., Salama, S. R., et al. (2013). The somatic genomic landscape of glioblastoma. Cell 155, 462-477. doi: 10.1016/j.cell.2013.09.034

Buchheit, C. L., Weigel, K. J., and Schafer, Z. T. (2014). Cancer cell survival during detachment from the ECM: multiple barriers to tumour progression. Nat. Rev. Cancer 14, 632-641. doi: 10.1038/nrc3789

Cantor, J. M., Rose, D. M., Slepak, M., and Ginsberg, M. H. (2015). Fine-tuning tumor immunity with integrin trans-regulation. Cancer Immunol. Res. 3, 661-667. doi: 10.1158/2326-6066.CIR13-0226

Carbonell, W. S., DeLay, M., Jahangiri, A., Park, C. C., and Aghi, M. K. (2013). betal integrin targeting potentiates antiangiogenic therapy and inhibits the growth of bevacizumab-resistant glioblastoma. Cancer Res. 73, 3145-3154. doi: 10.1158/0008-5472.CAN-13-0011
Est), by the Fondation ARC pour le Recherche sur le Cancer, by the Cancéropôle Grand Est and the Region Alsace. Anne Florence Blandin and Guillaume Renner are predoctoral fellows from the French Ministère de la Recherche et de l'Enseignement Supérieur.

Caswell, P. T., Chan, M., Lindsay, A. J., McCaffrey, M. W., Boettiger, D., and Norman, J. C. (2008). Rab-coupling protein coordinates recycling of alpha5betal integrin and EGFR1 to promote cell migration in 3D microenvironments. J. Cell Biol. 183, 143-155. doi: 10.1083/jcb.200804140

Chen, C. C., Kim, K. H., and Lau, L. F. (2015). The matricellular protein CCN1 suppresses hepatocarcinogenesis by inhibiting compensatory proliferation. Oncogene. doi: 10.1038/onc.2015.190. [Epub ahead of print].

Cheng, Y. J., Zhu, Z. X., Zhou, J. S., Hu, Z. Q., Zhang, J. P., Cai, Q. P., et al. (2015). Silencing profilin-1 inhibits gastric cancer progression via integrin beta1/focal adhesion kinase pathway modulation. World J. Gastroenterol. 21, 2323-2335. doi: 10.3748/wjg.v21.i8.2323

Ciriello, G., Miller, M. L., Aksoy, B. A., Senbabaoglu, Y., Schultz, N., and Sander, C. (2013). Emerging landscape of oncogenic signatures across human cancers. Nat. Genet. 45, 1127-1133. doi: 10.1038/ng.2762

de Groot, J. F., Fuller, G., Kumar, A. J., Piao, Y., Eterovic, K., Ji, Y., et al. (2010). Tumor invasion after treatment of glioblastoma with bevacizumab: radiographic and pathologic correlation in humans and mice. Neuro Oncol. 12, 233-242. doi: 10.1093/neuonc/nop027

DeLay, M., Jahangiri, A., Carbonell, W. S., Hu, Y. L., Tsao, S., Tom, M. W., et al. (2012). Microarray analysis verifies two distinct phenotypes of glioblastomas resistant to antiangiogenic therapy. Clin. Cancer Res. 18, 2930-2942. doi: 10.1158/1078-0432.CCR-11-2390

Desgrosellier, J. S., and Cheresh, D. A. (2010). Integrins in cancer: biological implications and therapeutic opportunities. Nat. Rev. Cancer 10, 9-22. doi: $10.1038 / \mathrm{nrc} 2748$

Dickreuter, E., Eke, I., Krause, M., Borgmann, K., van Vugt, M. A., and Cordes, N. (2015). Targeting of betal integrins impairs DNA repair for radiosensitization of head and neck cancer cells. Oncogene. doi: 10.1038/onc.2015.212. [Epub ahead of print].

Dong, X., Hudson, N. E., Lu, C., and Springer, T. A. (2014). Structural determinants of integrin beta-subunit specificity for latent TGF-beta. Nat. Struct. Mol. Biol. 21, 1091-1096. doi: 10.1038/nsmb.2905

Ducassou, A., Uro-Coste, E., Verrelle, P., Filleron, T., Benouaich-Amiel, A., Lubrano, V., et al. (2013). alphavbeta3 Integrin and Fibroblast growth factor receptor 1 (FGFR1): prognostic factors in a phase I-II clinical trial associating continuous administration of Tipifarnib with radiotherapy for patients with newly diagnosed glioblastoma. Eur. J. Cancer 49, 2161-2169. doi: 10.1016/j.ejca.2013.02.033

Eberwein, P., Laird, D., Schulz, S., Reinhard, T., Steinberg, T., and Tomakidi, P. (2015). Modulation of focal adhesion constituents and their down-stream events by EGF: on the cross-talk of integrins and growth factor receptors. Biochim. Biophys. Acta 1853, 2183-2198. doi: 10.1016/j.bbamcr.2015.06.004

Eke, I., and Cordes, N. (2015). Focal adhesion signaling and therapy resistance in cancer. Semin. Cancer Biol. 31, 65-75. doi: 10.1016/j.semcancer.2014.07.009

Eke, I., Deuse, Y., Hehlgans, S., Gurtner, K., Krause, M., Baumann, M., et al. (2012). beta(1)Integrin/FAK/cortactin signaling is essential for human head and neck cancer resistance to radiotherapy. J. Clin. Invest. 122, 1529-1540. doi: 10.1172/JCI61350

Eke, I., Storch, K., Krause, M., and Cordes, N. (2013). Cetuximab attenuates its cytotoxic and radiosensitizing potential by inducing fibronectin biosynthesis. Cancer Res. 73, 5869-5879. doi: 10.1158/0008-5472.CAN13-0344

Eke, I., Zscheppang, K., Dickreuter, E., Hickmann, L., Mazzeo, E., Unger, K., et al. (2015). Simultaneous betal integrin-EGFR targeting and radiosensitization of human head and neck cancer. J. Natl. Cancer Inst. 107:dju419. doi: 10.1093/jnci/ dju419

Esposito, M., and Kang, Y. (2014). Targeting tumor-stromal interactions in bone metastasis. Pharmacol. Ther. 141, 222-233. doi: 10.1016/j.pharmthera.2013.10.006 
Fabricius, E. M., Wildner, G. P., Kruse-Boitschenko, U., Hoffmeister, B., Goodman, S. L., and Raguse, J. D. (2011). Immunohistochemical analysis of integrins alphavbeta3, alphavbeta5 and alpha5beta1, and their ligands, fibrinogen, fibronectin, osteopontin and vitronectin, in frozen sections of human oral head and neck squamous cell carcinomas. Exp. Ther. Med. 2, 9-19. doi: 10.3892/etm.2010.171

Fedorenko, I. V., Abel, E. V., Koomen, J. M., Fang, B., Wood, E. R., Chen, Y. A., et al. (2015). Fibronectin induction abrogates the BRAF inhibitor response of BRAF V600E/PTEN-null melanoma cells. Oncogene. doi: 10.1038/ onc.2015.188. [Epub ahead of print].

Fennewald, S. M., Kantara, C., Sastry, S. K., and Resto, V. A. (2012). Laminin interactions with head and neck cancer cells under low fluid shear conditions lead to integrin activation and binding. J. Biol. Chem. 287, 21058-21066. doi: 10.1074/jbc.M112.360313

Gillory, L. A., Stewart, J. E., Megison, M. L., Waters, A. M., and Beierle, E. A. (2015). Focal adhesion kinase and p53 synergistically decrease neuroblastoma cell survival. J. Surg. Res. 196, 339-349. doi: 10.1016/j.jss.2015.03.021

Golubovskaya, V. M. (2014). Targeting FAK in human cancer: from finding to first clinical trials. Front. Biosci. 19, 687-706. doi: 10.2741/4236

Golubovskaya, V. M., and Cance, W. G. (2011). FAK and p53 protein interactions. Anticancer. Agents Med. Chem. 11, 617-619. doi: 10.2174/187152011796817619

Golubovskaya, V. M., Finch, R., Kweh, F., Massoll, N. A., Campbell-Thompson, M., Wallace, M. R., et al. (2008). p53 regulates FAK expression in human tumor cells. Mol. Carcinog. 47, 373-382. doi: 10.1002/mc.20395

Griffiths, G. S., Grundl, M., Leychenko, A., Reiter, S., Young-Robbins, S. S., Sulzmaier, F. J., et al. (2011). Bit-1 mediates integrin-dependent cell survival through activation of the NFkappaB pathway. J. Biol. Chem. 286, 14713-14723. doi: 10.1074/jbc.M111.228387

Guo, G., Gong, K., Wohlfeld, B., Hatanpaa, K. J., Zhao, D., and Habib, A. A. (2015). Ligand-Independent EGFR Signaling. Cancer Res. 75, 3436-3441. doi: 10.1158/0008-5472.CAN-15-0989

Hakanpaa, L., Sipila, T., Leppanen, V. M., Gautam, P., Nurmi, H., Jacquemet, G., et al. (2015). Endothelial destabilization by angiopoietin-2 via integrin betal activation. Nat. Commun. 6, 5962. doi: 10.1038/ncomms6962

Han, S., Li, Z., Master, L. M., Master, Z. W., and Wu, A. (2014). Exogenous IGFBP2 promotes proliferation, invasion, and chemoresistance to temozolomide in glioma cells via the integrin betal-ERK pathway. Br. J. Cancer. 111, 1400-1409. doi: 10.1038/bjc.2014.435

Hanahan, D., and Weinberg, R. A. (2000). The hallmarks of cancer. Cell 100, 57-70. doi: 10.1016/S0092-8674(00)81683-9

Hanahan, D., and Weinberg, R. A. (2011). Hallmarks of cancer: the next generation. Cell 144, 646-674. doi: 10.1016/j.cell.2011.02.013

Hanein, D., and Horwitz, A. R. (2012). The structure of cell-matrix adhesions: the new frontier. Curr. Opin. Cell Biol. 24, 134-140. doi: 10.1016/j.ceb.2011.12.001

Hirata, E., Girotti, M. R., Viros, A., Hooper, S., Spencer-Dene, B., Matsuda, M., et al. (2015). Intravital imaging reveals how BRAF inhibition generates drug-tolerant microenvironments with high integrin beta1/FAK signaling. Cancer Cell. 27, 574-588. doi: 10.1016/j.ccell.2015.03.008

Hohenester, E. (2014). Signalling complexes at the cell-matrix interface. Curr. Opin. Struct. Biol. 29, 10-16. doi: 10.1016/j.sbi.2014.08.009

Holmes, K. M., Annala, M., Chua, C. Y., Dunlap, S. M., Liu, Y., Hugen, N., et al. (2012). Insulin-like growth factor-binding protein 2-driven glioma progression is prevented by blocking a clinically significant integrin, integrin-linked kinase, and NF-kappaB network. Proc. Natl. Acad. Sci. U.S.A. 109, 3475-3480. doi: 10.1073/pnas.1120375109

Hongu, T., Funakoshi, Y., Fukuhara, S., Suzuki, T., Sakimoto, S., Takakura, N., et al. (2015). Arf6 regulates tumour angiogenesis and growth through HGFinduced endothelial beta1 integrin recycling. Nat. Commun. 6, 7925. doi: $10.1038 /$ ncomms 8925

Howe, G. A., and Addison, C. L. (2012). betal integrin: an emerging player in the modulation of tumorigenesis and response to therapy. Cell Adh. Migr. 6, 71-77. doi: $10.4161 /$ cam. 20077

Hu, C., Ni, Z., Li, B. S., Yong, X., Yang, X., Zhang, J. W., et al. (2015). hTERT promotes the invasion of gastric cancer cells by enhancing FOXO3a ubiquitination and subsequent ITGB1 upregulation. Gut. doi: 10.1136/gutjnl2015-309322. [Epub ahead of print].

Huang, C., Park, C. C., Hilsenbeck, S. G., Ward, R., Rimawi, M. F., Wang, Y. C., et al. (2011). betal integrin mediates an alternative survival pathway in breast cancer cells resistant to lapatinib. Breast Cancer Res. 13, R84. doi: $10.1186 /$ bcr2936

Huang, C. R., Lee, C. T., Chang, K. Y., Chang, W. C., Liu, Y. W., Lee, J. C., et al. (2015). Down-regulation of ARNT promotes cancer metastasis by activating the fibronectin/integrin beta1/FAK axis. Oncotarget 6, 11530-11546. doi: 10.18632/oncotarget.3448

Ivanova, I. A., Vermeulen, J. F., Ercan, C., Houthuijzen, J. M., Saig, F. A., Vlug, E. J., et al. (2013). FER kinase promotes breast cancer metastasis by regulating alpha6- and beta1-integrin-dependent cell adhesion and anoikis resistance. Oncogene 32, 5582-5592. doi: 10.1038/onc.2013.277

Ivaska, J., and Heino, J. (2011). Cooperation between integrins and growth factor receptors in signaling and endocytosis. Annu. Rev. Cell Dev. Biol. 27, 291-320. doi: 10.1146/annurev-cellbio-092910-154017

Jachetti, E., Caputo, S., Mazzoleni, S., Brambillasca, C. S., Parigi, S. M., Grioni, M., et al. (2015). Tenascin-C protects cancer stem-like cells from immune surveillance by arresting T-cell activation. Cancer Res. 75, 2095-2108. doi: 10.1158/0008-5472.CAN-14-2346

Jahangiri, A., Aghi, M. K., and Carbonell, W. S. (2014). betal integrin: critical path to antiangiogenic therapy resistance and beyond. Cancer Res. 74, 3-7. doi: 10.1158/0008-5472.CAN-13-1742

Janes, S. M., and Watt, F. M. (2004). Switch from alphavbeta5 to alphavbeta6 integrin expression protects squamous cell carcinomas from anoikis. J. Cell Biol. 166, 419-431. doi: 10.1083/jcb.200312074

Janouskova, H., Maglott, A., Leger, D. Y., Bossert, C., Noulet, F., Guerin, E., et al. (2012). Integrin alpha5betal plays a critical role in resistance to temozolomide by interfering with the p53 pathway in high-grade glioma. Cancer Res. 72, 3463-3470. doi: 10.1158/0008-5472.CAN-11-4199

Janouskova, H., Ray, A. M., Noulet, F., Lelong-Rebel, I., Choulier, L., Schaffner, F., et al. (2013). Activation of p53 pathway by Nutlin-3a inhibits the expression of the therapeutic target alpha5 integrin in colon cancer cells. Cancer Lett. 336, 307-318. doi: 10.1016/j.canlet.2013.03.018

Jinushi, M., Chiba, S., Baghdadi, M., Kinoshita, I., Dosaka-Akita, H., Ito, K., et al. (2012). ATM-mediated DNA damage signals mediate immune escape through integrin-alphavbeta3-dependent mechanisms. Cancer Res. 72, 56-65. doi: 10.1158/0008-5472.CAN-11-2028

Ju, L., and Zhou, C. (2013). Association of integrin betal and c-MET in mediating EGFR TKI gefitinib resistance in non-small cell lung cancer. Cancer Cell Int. 13:15. doi: 10.1186/1475-2867-13-15

Jung, A., Ray, A. M., Ramolu, L., Macabre, C., Simon, F., Noulet, F., et al. (2015). Caveolin-1-negative head and neck squamous cell carcinoma primary tumors display increased EMT and pro-metastatic properties. Oncotarget. doi: 10.18632/oncotarget.6099. [Epub ahead of print].

Kanda, R., Kawahara, A., Watari, K., Murakami, Y., Sonoda, K., Maeda, M., et al. (2013). Erlotinib resistance in lung cancer cells mediated by integrin beta1/Src/Akt-driven bypass signaling. Cancer Res. 73, 6243-6253. doi: 10.1158/0008-5472.CAN-12-4502

Lahlou, H., and Muller, W. J. (2011). betal-integrins signaling and mammary tumor progression in transgenic mouse models: implications for human breast cancer. Breast Cancer Research 13, 229. doi: 10.1186/bcr2905

Lanvin, O., Monferran, S., Delmas, C., Couderc, B., Toulas, C., and CohenJonathan-Moyal, E. (2013). Radiation-induced mitotic cell death and glioblastoma radioresistance: a new regulating pathway controlled by integrinlinked kinase, hypoxia-inducible factor 1 alpha and survivin in U87 cells. Eur. J. Cancer. 49, 2884-2891. doi: 10.1016/j.ejca.2013.05.003

Lee, J. G., Ahn, J. H., Jin Kim, T., Ho Lee, J., and Choi, J. H. (2015). Mutant p53 promotes ovarian cancer cell adhesion to mesothelial cells via integrin beta4 and Akt signals. Sci. Rep. 5:12642. doi: 10.1038/srep12642

Leyme, A., Marivin, A., Perez-Gutierrez, L., Nguyen, L. T., and Garcia-Marcos, M. (2015). Integrins activate trimeric $G$ proteins via the nonreceptor protein GIV/Girdin. J. Cell Biol. 210, 1165-1184. doi: 10.1083/jcb.2015 06041

Li, X., Ishihara, S., Yasuda, M., Nishioka, T., Mizutani, T., Ishikawa, M., et al. (2013). Lung cancer cells that survive ionizing radiation show increased integrin alpha2beta1 - and EGFR-dependent invasiveness. PLoS ONE. 8:e70905. doi: 10.1371/journal.pone.0070905

Liu, C. C., Leclair, P., Yap, S. Q., and Lim, C. J. (2013). The membrane-proximal KXGFFKR motif of alpha-integrin mediates chemoresistance. Mol. Cell. Biol. 33, 4334-4345. doi: 10.1128/MCB.00580-13 
Ma, J., Cai, W., Zhang, Y., Huang, C., Zhang, H., Liu, J., et al. (2013). Innate immune cell-derived microparticles facilitate hepatocarcinoma metastasis by transferring integrin alpha(M)beta(2) to tumor cells. J. Immunol. 191, 3453-3461. doi: 10.4049/jimmunol.1300171

Mai, A., Muharram, G., Barrow-McGee, R., Baghirov, H., Rantala, J., Kermorgant, S., et al. (2014). Distinct c-Met activation mechanisms induce cell rounding or invasion through pathways involving integrins, RhoA and HIP1. J. Cell Sci. 127, 1938-1952. doi: 10.1242/jcs.140657

Martin, S., Janouskova, H., and Dontenwill, M. (2012). Integrins and p53 pathways in glioblastoma resistance to temozolomide. Front. Oncol. 2:157. doi: 10.3389/fonc.2012.00157

Martinkova, E., Maglott, A., Leger, D. Y., Bonnet, D., Stiborova, M., Takeda, K., et al. (2010). alpha5betal integrin antagonists reduce chemotherapyinduced premature senescence and facilitate apoptosis in human glioblastoma cells. Int. J. Cancer J. Int. du Cancer 127, 1240-1248. doi: 10.1002/ijc. 25187

McGrail, D. J., Khambhati, N. N., Qi, M. X., Patel, K. S., Ravikumar, N., Brandenburg, C. P., et al. (2015). Alterations in ovarian cancer cell adhesion drive taxol resistance by increasing microtubule dynamics in a FAK-dependent manner. Sci. Rep. 5:9529. doi: 10.1038/srep09529

Missan, D. S., Mitchell, K., Subbaram, S., and DiPersio, C. M. (2015). Integrin alpha3betal signaling through MEK/ERK determines alternative polyadenylation of the MMP-9 mRNA transcript in immortalized mouse keratinocytes. PLoS ONE 10:e0119539. doi: 10.1371/journal.pone.01 19539

Monferran, S., Skuli, N., Delmas, C., Favre, G., Bonnet, J., Cohen-Jonathan-Moyal, E., et al. (2008). Alphavbeta3 and alphavbeta5 integrins control glioma cell response to ionising radiation through ILK and RhoB. Int. J. Cancer J. Int. du Cancer 123, 357-364. doi: 10.1002/ijc.23498

Morello, V., Cabodi, S., Sigismund, S., Camacho-Leal, M. P., Repetto, D., Volante, M., et al. (2011). betal integrin controls EGFR signaling and tumorigenic properties of lung cancer cells. Oncogene 30, 4087-4096. doi: 10.1038/onc.2011.107

Moreno-Layseca, P., and Streuli, C. H. (2014). Signalling pathways linking integrins with cell cycle progression. Matrix Biol. 34, 144-153. doi: 10.1016/j.matbio.2013.10.011

Moro, L., Dolce, L., Cabodi, S., Bergatto, E., Boeri Erba, E., Smeriglio, M., et al. (2002). Integrin-induced epidermal growth factor (EGF) receptor activation requires c-Src and p130Cas and leads to phosphorylation of specific EGF receptor tyrosines. J. Biol. Chem. 277, 9405-9414. doi: 10.1074/jbc.M1091 01200

Morozevich, G. E., Kozlova, N. I., Susova, O. Y., Karalkin, P. A., and Berman, A. E. (2015). Implication of alpha2betal integrin in anoikis of MCF7 human breast carcinoma cells. Biochem. Biokhimiia. 80, 97-103. doi: 10.1134/S0006297915010113

Morozevich, G. E., Kozlova, N. I., Ushakova, N. A., Preobrazhenskaya, M. E., and Berman, A. E. (2012). Integrin alpha5betal simultaneously controls EGFR-dependent proliferation and Akt-dependent pro-survival signaling in epidermoid carcinoma cells. Aging. 4, 368-374.

Muharram, G., Sahgal, P., Korpela, T., De Franceschi, N., Kaukonen, R., Clark, K., et al. (2014). Tensin-4-dependent MET stabilization is essential for survival and proliferation in carcinoma cells. Dev. Cell 29, 421-436. doi: 10.1016/j.devcel.2014.03.024

Murphy, P. A., Begum, S., and Hynes, R. O. (2015). Tumor angiogenesis in the absence of fibronectin or its cognate integrin receptors. PLOS ONE 10:e120872. doi: 10.1371/journal.pone.0120872

Naci, D., El Azreq, M. A., Chetoui, N., Lauden, L., Sigaux, F., Charron, D., et al. (2012). alpha2betal integrin promotes chemoresistance against doxorubicin in cancer cells through extracellular signal-regulated kinase (ERK). J. Biol. Chem. 287, 17065-17076. doi: 10.1074/jbc.M112. 349365

Naci, D., Vuori, K., and Aoudjit, F. (2015). Alpha2betal integrin in cancer development and chemoresistance. Semin. Cancer Biol. 35, 145-153. doi: 10.1016/j.semcancer.2015.08.004

Nam, J. M., Ahmed, K. M., Costes, S., Zhang, H., Onodera, Y., Olshen, A. B., et al. (2013). beta1-Integrin via NF-kappaB signaling is essential for acquisition of invasiveness in a model of radiation treated in situ breast cancer. Breast Cancer Res. 15, R60. doi: 10.1186/bcr3454
Nam, J. M., Chung, Y., Hsu, H. C., and Park, C. C. (2009). beta1 integrin targeting to enhance radiation therapy. Int. J. Radiat. Biol. 85, 923-928. doi: $10.3109 / 09553000903232876$

Navab, R., Strumpf, D., To, C., Pasko, E., Kim, K. S., Park, C. J., et al. (2015). Integrin alpha11betal regulates cancer stromal stiffness and promotes tumorigenicity and metastasis in non-small cell lung cancer. Oncogene. doi: 10.1038/onc.2015.254. [Epub ahead of print].

Ning, S., Tian, J., Marshall, D. J., and Knox, S. J. (2010). Anti-alphav integrin monoclonal antibody intetumumab enhances the efficacy of radiation therapy and reduces metastasis of human cancer xenografts in nude rats. Cancer Res. 70, 7591-7599. doi: 10.1158/0008-5472.CAN-10-1639

Nistico, P., Di Modugno, F., Spada, S., and Bissell, M. J. (2014). betal and beta4 integrins: from breast development to clinical practice. Breast Cancer Res. 16:459. doi: 10.1186/s13058-014-0459-x

Nunes, J. B., Peixoto, J., Soares, P., Maximo, V., Carvalho, S., Pinho, S. S., et al. (2015). OXPHOS dysfunction regulates integrin-betal modifications and enhances cell motility and migration. Hum. Mol. Genet. 24, 1977-1990. doi: 10.1093/hmg/ddu612

Oommen, S., Gupta, S. K., and Vlahakis, N. E. (2011). Vascular endothelial growth factor A (VEGF-A) induces endothelial and cancer cell migration through direct binding to integrin \{alpha\}9\{beta\}1: identification of a specific \{alpha\}9\{beta\}1 binding site. J. Biol. Chem. 286, 1083-1092. doi: 10.1074/jbc.M110.175158

Paoli, P., Giannoni, E., and Chiarugi, P. (2013). Anoikis molecular pathways and its role in cancer progression. Biochim. Biophys. Acta. 1833, 3481-3498. doi: 10.1016/j.bbamcr.2013.06.026

Paul, N. R., Allen, J. L., Chapman, A., Morlan-Mairal, M., Zindy, E., Jacquemet, G., et al. (2015). alpha5betal integrin recycling promotes Arp2/3-independent cancer cell invasion via the formin FHOD3. J. Cell Biol. 210, 1013-1031. doi: $10.1083 /$ jcb. 201502040

Paulus, W., Baur, I., Schuppan, D., and Roggendorf, W. (1993). Characterization of integrin receptors in normal and neoplastic human brain. Am. J. Pathol. 143, 154-163.

Pelillo, C., Bergamo, A., Mollica, H., Bestagno, M., and Sava, G. (2015). Colorectal cancer metastases settle in the hepatic microenvironment through alpha5beta1 integrin. J. Cell. Biochem. 116, 2385-2396. doi: 10.1002/jcb.25189

Petrás, M., Lajtos, T., Friedländer, E., Klekner, A., Pintye, E., Feuerstein, B. G., et al. (2013). Molecular interactions of ErbB1 (EGFR) and integrinbetal in astrocytoma frozen sections predict clinical outcome and correlate with Akt-mediated in vitro radioresistance. Neuro Oncol. 15, 1027-1040. doi: 10.1093/neuonc/not046

Pickup, M. W., Mouw, J. K., and Weaver, V. M. (2014). The extracellular matrix modulates the hallmarks of cancer. EMBO Rep. 15, 1243-1253. doi: 10.15252/embr.201439246

Poschau, M., Dickreuter, E., Singh-Mäller, J., Zscheppang, K., Eke, I., Liersch, T. et al. (2015). EGFR and beta1-integrin targeting differentially affect colorectal carcinoma cell radiosensitivity and invasion. Radiother. Oncol. 116, 510-516. doi: 10.1016/j.radonc.2015.06.005

Renner, G., Janouskova, H., Noulet, F., Koenig, V., Guerin, E., Bär, S., et al. (2015). Integrin alpha5betal and p53 convergent pathways in the control of anti-apoptotic proteins PEA-15 and survivin in high-grade glioma. Cell Death Different . doi: 10.1038/cdd.2015.131. [Epub ahead of print].

Robertson, J., Jacquemet, G., Byron, A., Jones, M. C., Warwood, S., Selley, J. N., et al. (2015). Defining the phospho-adhesome through the phosphoproteomic analysis of integrin signalling. Nat. Commun. 6, 6265. doi: $10.1038 /$ ncomms 7265

Robinson, S. D., Reynolds, L. E., Kostourou, V., Reynolds, A. R., da Silva, R. G., Tavora, B., et al. (2009). Alphav beta3 integrin limits the contribution of neuropilin-1 to vascular endothelial growth factor-induced angiogenesis. J. Biol. Chem. 284, 33966-33981. doi: 10.1074/jbc.M109.030700

Rossier, O., Octeau, V., Sibarita, J. B., Leduc, C., Tessier, B., Nair, D., et al. (2012). Integrins betal and beta3 exhibit distinct dynamic nanoscale organizations inside focal adhesions. Nat. Cell Biol. 14, 1057-1067. doi: 10.1038/ ncb2588

Savar, A., Acin, S., Gonzalez, C. L., El-Sawy, T., Mejia, O., Li, Z., et al. (2015). Loss of epithelial p53 and alphav integrin cooperate through Akt to induce squamous cell carcinoma yet prevent remodeling of the tumor microenvironment. Oncogene 34, 516-524. doi: 10.1038/onc.2013.585 
Scales, T. M., and Parsons, M. (2011). Spatial and temporal regulation of integrin signalling during cell migration. Curr. Opin. Cell Biol. 23, 562-568. doi: 10.1016/j.ceb.2011.05.008

Schaffner, F., Ray, A. M., and Dontenwill, M. (2013). Integrin alpha5beta1, the fibronectin receptor, as a pertinent therapeutic target in solid tumors. Cancers 5, 27-47. doi: 10.3390/cancers5010027

Schempp, C. M., von Schwarzenberg, K., Schreiner, L., Kubisch, R., Muller, R., Wagner, E., et al. (2014). V-ATPase inhibition regulates anoikis resistance and metastasis of cancer cells. Mol. Cancer Ther. 13, 926-937. doi: 10.1158/15357163.MCT-13-0484

Schlomann, U., Koller, G., Conrad, C., Ferdous, T., Golfi, P., Garcia, A. M., et al. (2015). ADAM8 as a drug target in pancreatic cancer. Nat. Commun. 6, 6175. doi: $10.1038 /$ ncomms7175

Seguin, L., Desgrosellier, J. S., Weis, S. M., and Cheresh, D. A. (2015). Integrins and cancer: regulators of cancer stemness, metastasis, and drug resistance. Trends Cell Biol. 25, 234-240. doi: 10.1016/j.tcb.2014. 12.006

Seguin, L., Kato, S., Franovic, A., Camargo, M. F., Lesperance, J., Elliott, K. C., et al. (2014). An integrin beta(3)-KRAS-RalB complex drives tumour stemness and resistance to EGFR inhibition. Nat. Cell Biol. 16, 457-468. doi: 10.1038/ ncb2953

Selivanova, G. (2014). Wild type p53 reactivation: from lab bench to clinic. FEBS Lett. 588, 2628-2638. doi: 10.1016/j.febslet.2014.03.049

Shishido, S., Bönig, H., and Kim, Y. M. (2014). Role of integrin alpha4 in drug resistance of leukemia. Front. Oncol. 4:99. doi: 10.3389/fonc.2014.00099

Silginer, M., Weller, M., Ziegler, U., and Roth, P. (2014). Integrin inhibition promotes atypical anoikis in glioma cells. Cell Death Dis. 5, e1012. doi: $10.1038 /$ cddis. 2013.543

Skuli, N., Monferran, S., Delmas, C., Favre, G., Bonnet, J., Toulas, C., et al. (2009). Alphavbeta3/alphavbeta5 integrins-FAK-RhoB: a novel pathway for hypoxia regulation in glioblastoma. Cancer Res. 69, 3308-3316. doi: 10.1158/00085472.CAN-08-2158

Soares, M. Q., Mendonca, J. A., Morais, M. O., Leles, C. R., Batista, A. C., and Mendonca, E. F. (2015). E-cadherin, $\beta$-catenin, and $\alpha 2 \beta 1$ and $\alpha 3 \beta 1$ integrin expression in primary oral squamous cell carcinoma and its regional metastasis. Histol. Histopathol. 30, 1213-1222. doi: 10.14670/HH-11-616

Sørensen, B. H., Rasmussen, L. J., Broberg, B. S., Klausen, T. K., Sauter, D. P., Lambert, I. H., et al. (2015). Integrin beta1, osmosensing, and chemoresistance in mouse ehrlich carcinoma cells. Cell. Physiol. Biochem. 36, 111-132. doi: 10.1159/000374057

Speicher, T., Siegenthaler, B., Bogorad, R. L., Ruppert, R., Petzold, T., PadrissaAltes, S., et al. (2014). Knockdown and knockout of beta1-integrin in hepatocytes impairs liver regeneration through inhibition of growth factor signalling. Nat. Commun. 5, 3862. doi: 10.1038/ncomms 4862

Steglich, A., Vehlow, A., Eke, I., and Cordes, N. (2015). alpha integrin targeting for radiosensitization of three-dimensionally grown human head and neck squamous cell carcinoma cells. Cancer Lett. 357, 542-548. doi: 10.1016/j.canlet.2014.12.009

Steri, V., Ellison, T. S., Gontarczyk, A. M., Weilbaecher, K., Schneider, J. G., Edwards, D., et al. (2014). Acute depletion of endothelial beta3-integrin transiently inhibits tumor growth and angiogenesis in mice. Circ. Res. 114, 79-91. doi: 10.1161/CIRCRESAHA.114.301591

Stupp, R., Hegi, M. E., Gorlia, T., Erridge, S. C., Perry, J., Hong, Y. K., et al. (2014). Cilengitide combined with standard treatment for patients with newly diagnosed glioblastoma with methylated MGMT promoter (CENTRIC EORTC 26071-22072 study): a multicentre, randomised, openlabel, phase 3 trial. Lancet Oncol.15, 1100-1108. doi: 10.1016/S1470-2045(14) 70379-1

Stupp, R., Hegi, M. E., Neyns, B., Goldbrunner, R., Schlegel, U., Clement, P. M., et al. (2010). Phase I/IIa study of cilengitide and temozolomide with concomitant radiotherapy followed by cilengitide and temozolomide maintenance therapy in patients with newly diagnosed glioblastoma. J. Clin. Oncol. 28, 2712-2718. doi: 10.1200/JCO.2009. 26.6650

Tanaka, R., Seki, Y., Saito, Y., Kamiya, S., Fujita, M., Okutsu, H., et al. (2014). Tenascin-C-derived peptide TNIIIA2 highly enhances cell survival and platelet-derived growth factor (PDGF)-dependent cell proliferation through potentiated and sustained activation of integrin alpha5beta1. J. Biol. Chem. 289, 17699-17708. doi: 10.1074/jbc.M113.546622

Toricelli, M., Melo, F. H., Peres, G. B., Silva, D. C., and Jasiulionis, M. G. (2013). Timp1 interacts with beta-1 integrin and CD63 along melanoma genesis and confers anoikis resistance by activating PI3-K signaling pathway independently of Akt phosphorylation. Mol. Cancer 12:22. doi: 10.1186/1476-4598-12-22

Tseng, P. C., Chen, C. L., Shan, Y. S., Chang, W. T., Liu, H. S., Hong, T. M., et al. (2014). An increase in integrin-linked kinase non-canonically confers NF-kappaB-mediated growth advantages to gastric cancer cells by activating ERK1/2. Cell Commun. Signal. 12:69. doi: 10.1186/s12964-014-0069-3

Vachon, P. H. (2011). Integrin signaling, cell survival, and anoikis: distinctions, differences, and differentiation. J. Signal Transduct. 2011:738137. doi: $10.1155 / 2011 / 738137$

Veevers-Lowe, J., Ball, S. G., Shuttleworth, A., and Kielty, C. M. (2011). Mesenchymal stem cell migration is regulated by fibronectin through alpha5beta1-integrin-mediated activation of PDGFR-beta and potentiation of growth factor signals. J. Cell Sci. 124, 1288-1300. doi: 10.1242/jcs.076935

Vial, D., and McKeown-Longo, P. J. (2012). Epidermal growth factor (EGF) regulates alpha5betal integrin activation state in human cancer cell lines through the p90RSK-dependent phosphorylation of filamin A. J. Biol. Chem. 287, 40371-40380. doi: 10.1074/jbc.M112.389577

Vitorino, P., Yeung, S., Crow, A., Bakke, J., Smyczek, T., West, K., et al. (2015). MAP4K4 regulates integrin-FERM binding to control endothelial cell motility. Nature 519, 425-430. doi: 10.1038/nature14323

Vlahakis, N. E., Young, B. A., Atakilit, A., and Sheppard, D. (2005). The lymphangiogenic vascular endothelial growth factors VEGF-C and -D are ligands for the integrin alpha9beta1. J. Biol. Chem. 280, 4544-4552. doi: 10.1074/jbc.M412816200

Wang, Y., Arjonen, A., Pouwels, J., Ta, H., Pausch, P., Bange, G., et al. (2015). Formin-like 2 Promotes beta1-Integrin trafficking and invasive motility downstream of PKCalpha. Dev. Cell 34, 475-483. doi: 10.1016/j.devcel.2015.06.015

Williams, K. C., and Coppolino, M. G. (2014). SNARE-dependent interaction of Src, EGFR and betal integrin regulates invadopodia formation and tumor cell invasion. J. Cell Sci. 127, 1712-1725. doi: 10.1242/jcs.134734

Winograd-Katz, S. E., Fässler, R., Geiger, B., and Legate, K. R. (2014). The integrin adhesome: from genes and proteins to human disease. Nat. Rev. Mol. Cell Biol. 15, 273-288. doi: 10.1038/nrm3769

Wong, P. P., Demircioglu, F., Ghazaly, E., Alrawashdeh, W., Stratford, M. R., Scudamore, C. L., et al. (2015). Dual-action combination therapy enhances angiogenesis while reducing tumor growth and spread. Cancer Cell 27, 123-137. doi: 10.1016/j.ccell.2014.10.015

Yamamoto, H., Ehling, M., Kato, K., Kanai, K., van Lessen, M., Frye, M., et al. (2015). Integrin betal controls VE-cadherin localization and blood vessel stability. Nat. Commun.6, 6429. doi: 10.1038/ncomms7429

Yang, L., Hou, Y., Yuan, J., Tang, S., Zhang, H., Zhu, Q., et al. (2015). Twist promotes reprogramming of glucose metabolism in breast cancer cells through PI3K/AKT and p53 signaling pathways. Oncotarget 6, 25755-25769. doi: 10.18632/oncotarget.4697

Yang, P., Li, Z., Fu, R., Wu, H., and Li, Z. (2014). Pyruvate kinase M2 facilitates colon cancer cell migration via the modulation of STAT3 signalling. Cell. Signal. 26, 1853-1862. doi: 10.1016/j.cellsig.2014.03.020

Yuan, J., Liu, M., Yang, L., Tu, G., Zhu, Q., Chen, M., et al. (2015). Acquisition of epithelial-mesenchymal transition phenotype in the tamoxifen-resistant breast cancer cell: a new role for $\mathrm{G}$ protein-coupled estrogen receptor in mediating tamoxifen resistance through cancer-associated fibroblast-derived fibronectin and betal-integrin signaling pathway in tumor cells. Breast Cancer Res. 17, 69. doi: 10.1186/s13058-015-0579-y

Zhang, H. F., Alshareef, A., Wu, C., Li, S., Jiao, J. W., Cao, H. H., et al. (2015a). Loss of miR-200b promotes invasion via activating the Kindlin2/integrin beta1/AKT pathway in esophageal squamous cell carcinoma: an Ecadherin-independent mechanism. Oncotarget 6, 28949-28960. doi: 10.18632/ oncotarget.5027

Zhang, X., Cheng, S. L., Bian, K., Wang, L., Zhang, X., Yan, B., et al. (2015b). MicroRNA-26a promotes anoikis in human hepatocellular carcinoma cells by targeting alpha5 integrin. Oncotarget. 6, 2277-2289. doi: 10.18632/oncotarget.2956 
Zhou, P., Erfani, S., Liu, Z., Jia, C., Chen, Y., Xu, B., et al. (2015). CD151alpha3beta1 integrin complexes are prognostic markers of glioblastoma and cooperate with EGFR to drive tumor cell motility and invasion. Oncotarget 6, 29675-29693. doi: 10.18632/oncotarget.4896

Zhu, J., and Clark, R. A. (2014). Fibronectin at select sites binds multiple growth factors and enhances their activity: expansion of the collaborative ECM-GF paradigm. J. Invest. Dermatol. 134, 895-901. doi: 10.1038/jid.2013.484

Zoni, E., van der Horst, G., van de Merbel, A. F., Chen, L., Rane, J. K., Pelger, R. C., et al. (2015). miR-25 modulates invasiveness and dissemination of human prostate cancer cells via regulation of alphav- and alpha6-Integrin expression. Cancer Res. 75, 2326-2336. doi: 10.1158/0008-5472.CAN-14-2155
Conflict of Interest Statement: The authors declare that the research was conducted in the absence of any commercial or financial relationships that could be construed as a potential conflict of interest.

Copyright $\odot 2015$ Blandin, Renner, Lehmann, Lelong-Rebel, Martin and Dontenwill. This is an open-access article distributed under the terms of the Creative Commons Attribution License (CC BY). The use, distribution or reproduction in other forums is permitted, provided the original author(s) or licensor are credited and that the original publication in this journal is cited, in accordance with accepted academic practice. No use, distribution or reproduction is permitted which does not comply with these terms. 